\title{
PHYSICAL PROPERTIES REQUIRED FOR DETERMINING THE OPTIMAL HARVEST TIME OF SNAP BEANS AND SWEET PEA'S CROPS.
}

\author{
A.E. El-Raie ${ }^{1}$, Y.A. Bader ${ }^{2}$, H.E. Hassan ${ }^{3}$, and R. K. Ibrahim ${ }^{4}$
}

\begin{abstract}
The Egyptian Government has always been interested in increasing the horticultural "including vegetables" exports in order to increase the national income as well as the foreign exchange currency. Traditionally, growers always relay on their own experience when deciding on the maturity level of the vegetable crops and the optimal harvest time. The main objectives of this research are to determine the optimal harvest time for snap beans (Phaseolus vulgaris L. var Paulista) and Sweet pea's (Pisum Sativum L. var Sugar Lays) according to physical properties. The optimal harvest time of snap beans was specified as length ranged from 110 to $140 \mathrm{~mm}$, maximum diameter is ranged from 5.5 to $8.0 \mathrm{~mm}$, minimum diameter is ranged from 2.25 to $5 \mathrm{~mm}$, mass is ranged from 2.25 to $5 \mathrm{~g}$, and the moisture content is ranged from 91.17 to $89.8 \%$ at about 16 to 22 days from flower appears.

The optimal harvest time of sweet peas which has length ranged from 61 to $73 \mathrm{~mm}$, maximum diameter is ranged from 13 to $15 \mathrm{~mm}$, minimum diameter is ranged from 9 to $13 \mathrm{~mm}$, mass is ranged from 2.5 to $4.5 \mathrm{~g}$, and the moisture content is ranged from 88.5 to $87 \%$ at about 12 to 18 days from flower appears.
\end{abstract}

Key Words: Optimal harvest time, Snap beans, Sweet pea's, Physical properties.

\section{INTRODUCTION}

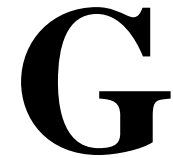

ast (1994) stated that the maturity for snap bean harvest is based on the diameter of the bean. Beans should be fairly straight and true the color. Specialized markets for French filt beans and baby beans accept size 1 and 2 beans. Size 6 beans could also be marketed as "shellie bean" beans sold for shelling out the beans inside and discarding the pod.

1- Prof. Dr., Agric. Eng. Dep., Fac. of Agreic., Cairo Univ., Egypt. 2\&3- Prof. Dr.,\& Assoc. Prof., Nat. Inst. of Laser Enhanced Sc., Cairo Univ., Egypt. 4- Researsher, Agric. Eng. Res. Inst, Agric. Res Center, Dokki, Egypt. 
These are especially marketable if the bean seed is colorful.

Salunkhe and Kadam (1998) graded peas for processing into four grades on the size of shelled peas. The smaller sizes are considered to have the best quality and fetch the highest prices from canners. The sieves used for separation the sizes have mesh ranging from 18/64 to $24 / 64$ in. in diameter.

Malik (2000) stated that for peas, manures and fertilizers at the rate of 20-25 t/ha should be added and worked into the soil. Superp hosphate at the rate of $350-400 \mathrm{~kg} / \mathrm{ha}$, and $100 \mathrm{~kg} / \mathrm{ha}$ of potassium sulphate or muriate of potash should be applied at final land preparation before sowing. A dressing of nitrogen as ammonium sulphate at the rate of 200$300 \mathrm{~kg} / \mathrm{ha}$ at the time of pod formation will be beneficial. The seed rate for an early crop is $100-120 \mathrm{~kg} / \mathrm{ha}$, whereas for a normal or late planting it is $80-90 \mathrm{~kg} / \mathrm{ha}$. The minimum temperature for germination is about $10^{\circ} \mathrm{C}$ and the optimum about $22^{\circ} \mathrm{C}$.

Singh et al. (2004) mentioned that the French bean pods should be harvested before they are fully grown and seeds are small. The period of first picking varies from 40 to 65 days after sowing, depending upon the variety and season of crop.

Acquaah (2005) stated that snap beans may be harvested 50 to 65 days after planting. They are ready for harvesting when they have attained physiological maturity, about two weeks after flowering.

Acquaah (2005) stated that the pea plant soil is fertile, well drained, and light textured. Because the pea plant is intolerant of high soil acidity, soil $\mathrm{pH}$ should be above 5.5 and up to 7 the soil should be well plowed and of good tilth. Plants are spaced about 2 inches (5.1 centimeters) in rows and 2 to 3 feet ( 0.61 to 0.91 meter) between rows. Plants may also be placed in double spaced about 6 inches (15.2 centimeters) apart.

Drost (2005) stated that snap peas are harvested before the pods are fully mature. Pods should be full size, with small seeds, and have firm, crisp flesh when picked. Snap peas are ready for harvest about 5-8 days after flowering. 
El-Raie et al. (2007) found that the number of pods per plant ranged from 40 to 50 pods with average 45 pods per plant and the average range of pods number in furrow zone, crown zone and upper canopy zone were 4-6 pods, 22-24 pods and 13-15 pods, respectively. They observed that $51 \%$ of pods mostly concentrated on the crown zone of the plant, $38 \%$ of pods concentrated in the upper canopy zone of the plant and $11 \%$ of pods concentrated in furrow zone of the plant.

The objectives of the present study are to:1- Measuring dimensions of green beans and peas pods at different ages can be used in sorting, grading and handling processes

2- Predicting the regression equations to express the relationships between different items to determining the optimal harvest time of pods.

\section{MATERIAL AND METHODS}

The samples of snap beans (Phaseolus vulgaris L. var Paulista) and sweet pea's or green pea's (Pisum Sativum L. var Sugar Lays) pods were obtained from the farm of the Central Laboratory for Agricultural Climate, Agricultural Research Center (ARC) at Dokki, Giza, ARE. The cultivated area was $540 \mathrm{~m}^{2}$ planted with snap bean seeds (Paulista var.) on winter season at 17/11/2005 under greenhouse (9x60m). The distance between rows was $70 \mathrm{~cm}$ and between plants was $25 \mathrm{~cm}$.

The area was cultivated with sweet peas seeds (Sugar lays var.) at $8 / 11 / 2006$. The distance between rows was $70 \mathrm{~cm}$ and between seeds was $10 \mathrm{~cm}$. It was fixed screen sheets between two rows to climbing the plants of green peas by its tendrils.

The soil was irrigated after 21 days from the $1 \stackrel{\text { st }}{\text { irrigation (planting }}$ irrigation). After that the plants were irrigated five times with an interval of 15 days.

For both snap beans and sweet pea's, before planting when prepared the seedbed, fertilization was applied using compost at a rate of $20 \mathrm{~m}^{3}$ /fed., and super phosphate at a rate of $200 \mathrm{~kg} / \mathrm{fed}$. $\left(30 \mathrm{~kg} \mathrm{P} \mathrm{O}_{5}\right)$. After planting, fertilization was applied using $100 \mathrm{~kg}$ of potassium sulphate $\left(50 \mathrm{~kg} \mathrm{~K}_{2} \mathrm{O}\right)$ as recommended by Ministry of Agriculture. snap bean samples (eight 
samples from the pods appear from its flowers to there become yellow and dry) were collected from 16/2/2006 to 8/5/2006 every three days and sweet peas samples (ten samples from appearing the pods to the yellow and dry stage) were collected from 7/2/2007 to 10/4/2007.

Electronic digital caliper (accuracy 0.02, Japan) was used to measure the dimensions of pods. Electric oven (Blue M, U.S.A) was used to determine the moisture content of samples. Pods of green beans and sweet peas were taken from the field at different ages. Pods were mass and oven dried to constant mass at $70^{\circ} \mathrm{C}$ for 24 hours.

Digital balance (Laptop balance LZ 5000, Japan) was used to determine the mass of snap beans and sweet pea's pods.

Moisture Content: Was calculated using the following formula:

$$
\Theta=\left(\mathbf{W}_{\mathbf{w}}-\mathbf{W}_{\mathbf{d}} / \mathbf{W}_{\mathbf{d}}\right) * \mathbf{1 0 0} \text {. }
$$

Where: $\Theta$ is the moisture content (d.b), \%;

$\mathrm{W}_{\mathrm{w}}$ - wet weight of the pods, $\mathrm{g}$; and

$\mathrm{W}_{\mathrm{d}}-$ dry weight of the pods, $\mathrm{g}$.

\section{RESULTS AND DISCUION}

Physical properties of snap beans and sweet pea's such as length, maximum diameter, minimum diameter, mass, and moisture content were measured for snap bean and sweet pea's pods at different ages from the appearance of the pods from their flowers (at the age of 8 for green beans pods and at the age of 10 for sweet pea pods which appear earlier than the green beans pods). The results of physical properties at different ages of samples were measured, calculated, statically analyzed and discussed as follow:

\section{Frequency distribution of some physical properties of pods:}

Most of lengths of snap bean pods were concentrated between 100 and $140 \mathrm{~mm}$ for ages between 13 and 28 days. The higher frequency peak was at age 10 days (22\% frequency). Although most of lengths of sweet pea pods were concentrated between 60 and $80 \mathrm{~mm}$ for ages between 12 and 30 days, the higher peak occurred at age 24 days (30\% frequency).

The sweet pea's pods were classified into three sizes: $<60 \mathrm{~mm}, 60-80$ $\mathrm{mm}$, and > $80 \mathrm{~mm}$ (according to Hazelton, 2006). 
According to that, the samples of 100 pods of green beans at each age of pods are graded to three sizes as follows:

$\begin{array}{llll}\text { Pods age, day } & <60 \mathrm{~mm} & 60-80 \mathrm{~mm} & >80 \mathrm{~mm} \\ 6 & 100 \% & 0 \% & 0 \% \\ 9 & 50 \% & 50 \% & 0 \% \\ 12 & 17 \% & 83 \% & 0 \% \\ 15 & 0 \% & 100 \% & 0 \% \\ 18 & 0 \% & 100 \% & 0 \% \\ 21 & 0 \% & 100 \% & 0 \% \\ 24 & 0 \% & 100 \% & 0 \% \\ 27 & 0 \% & 100 \% & 0 \% \\ 30 & 0 \% & 100 \% & 0 \% \\ 33 & 0 \% & 83 \% & 17 \%\end{array}$

It is noticed that all lengths of sweet pea's pods ranged from 15 to 30 days age are ranged between 60 and $80 \mathrm{~mm}$.

The frequent distribution of maximum diameters of snap bean pods were concentrated between 6 and $9 \mathrm{~mm}$. The higher peak of frequency was at age 28 days (23\% frequency). Although most of maximum diameters were concentrated between 14 and $16 \mathrm{~mm}$. The higher peak was at age 21 days (22\% frequency).

it can classify the green beans pods into three sizes: extra fine $<6.5 \mathrm{~mm}$, very fine $6.5-8 \mathrm{~mm}$ and fine $8-10 \mathrm{~mm}$ (according to Wien, 1997).

According to that, the samples of 100 pods of green beans at each age of pods are graded to three sizes as follows:

$\begin{array}{llll}\text { Pods age, day } & \text { Extra fine } & \text { Very fine } & \text { Fine } \\ 10 & 100 \% & 0 \% & 0 \% \\ 13 & 100 \% & 0 \% & 0 \% \\ 16 & 100 \% & 0 \% & 0 \% \\ 19 & 28 \% & 72 \% & 0 \% \\ 22 & 0 \% & 71 \% & 29 \% \\ 25 & 0 \% & 1 \% & 99 \% \\ 28 & 0 \% & 1 \% & 99 \% \\ 31 & 0 \% & 0 \% & 100 \%\end{array}$


It is noticed that, all green bean pods at ages from 10 to 16 are extra fine, most of pods at ages from 19 to 22 are very fine and all pods at ages from 25 to 31 are fine.

The frequency distribution of minimum diameters of green bean pods were concentrated between 5 and $8 \mathrm{~mm}$. The higher peak of frequency was at age 28 days ( $23 \%$ frequency). Although most of minimum diameters were concentrated between 11 and $15 \mathrm{~mm}$, the higher peak was at age 27 days (21\% frequency).

The frequency distribution of mass of green bean pods were concentrated between 2 and $5 \mathrm{~g}$. The higher peak of frequency was at ages 10, 16 days (21\% frequency). Although most of mass of sweet pea pods were concentrated between 3.5 and $5.5 \mathrm{~mm}$. The higher peak was between ages 9,30 days ( $21 \%$ frequency).

\section{Snap Bean Pods:}

Typical mean values obtained from large numbers of observations of snap bean pods at different ages from the appearance of the pods are given in Table (1). Data show that the length of green bean pods increased from 53.03 to $178.97 \mathrm{~mm}$ across different ages, the maximum and minimum diameter increased from 2.43 to $9.34 \mathrm{~mm}$ and from 2.26 to $9.16 \mathrm{~mm}$, for pods at the age from 10 to 31 days, respectively.

Moreover, data show that the mass increased from 0.78 to $8.19 \mathrm{~g}$, and the moisture content of pods decreased from 93.64 to $68.92 \%$ for pods at the age from 10 to 31 days from the appearance of their flowers.

It is noticed that the difference between maximum and minimum diameter is very small .They increased slowly when the age of green bean pods increased, while the length increased fast when the pod's age increased. Generally, the length was greater than diameter at different ages.

Using mean values shown in Table (1), the following general equations were deduced to express the relationships between length $(\mathrm{L})$, maximum diameter $\left(D_{1}\right)$, minimum diameter $\left(D_{2}\right)$ and mass $(M)$ of green bean pods at different ages from the appearance of the pods.

For the first age (pods at 10 days):

$\mathrm{L}=21.82 \mathrm{D}_{1}=23.46 \mathrm{D}_{2}=67.99 \mathrm{M}$

For pods at 16 days: 
$\mathrm{L}=19.53 \mathrm{D}_{1}=20.28 \mathrm{D}_{2}=48.87 \mathrm{M}$

For pods at 22 days:

$\mathrm{L}=17.89 \mathrm{D}_{1}=18.54 \mathrm{D}_{2}=31.51 \mathrm{M}$

For the last age (pods at 31 days):

$\mathrm{L}=19.16 \mathrm{D}_{1}=19.54 \mathrm{D}_{2}=21.85 \mathrm{M}$.

Generally, the following equations summarize the relationships between $\mathrm{L}, \mathrm{D}_{1}, \mathrm{D}_{2}$ and $\mathrm{M}$ as a function of the pod's age (A).

$\mathrm{L}=23.866+4.863 \mathrm{~A}, \mathrm{R}^{2}=0.893, \mathrm{~F}_{\text {Regression }}=6634$

$\mathrm{D}_{1}=0.550+0.302 \mathrm{~A}, \mathrm{R}^{2}=0.900, \mathrm{~F}_{\text {Regression }}=7216$

$\mathrm{D}_{2}=0.328+0.296 \mathrm{~A}, \mathrm{R}^{2}=0.904, \mathrm{~F}_{\text {Regression }}=7485$

$\mathrm{M}=0.331 \mathrm{~A}-2.894, \mathrm{R}^{2}=0.951, \mathrm{~F}_{\text {Regression }}=15563$

The equations (from 6 through 9) indicate that: the age of the pod affects the pod's length $(L)$, pod's maximum diameter $\left(D_{1}\right)$, pod's minimum diameter $\left(\mathrm{D}_{2}\right)$, and pod's mass $(\mathrm{M})$.

\subsection{Statistical analysis of samples:}

Typical mean values were obtained from 100 samples at each age from the appearance of the pods. The statically indices of the main dimensions, mass and moisture content such as variance $\left(\mathrm{S}^{2}\right)$, standard deviation $\left(\sigma_{\mathrm{n}-1}\right)$, standard error (S.E.), and coefficient of variance (C.V., \%) were calculated and tabulated in Table (2) to show the dispersion of the measured values around the mean value of green bean pods.

The maximum and minimum values of coefficient of variance (C.V.) were 0.080 and $0.008 \%$ for length at pods ages 13 and 16 days, respectively.

For maximum diameter, the maximum and minimum values were 0.121 and $0.018 \%$ for pods ages 13 and 31 days, respectively. Also, for minimum diameter, the maximum and minimum values were 0.126 and $0.024 \%$ at pods ages 10 and 31 days, respectively.

For mass, the maximum and minimum values were 0.530 and $0.45 \%$ for pods ages 31 and 25 days, respectively. 
Table (1): Typical mean of samples of 100 green beans pods at different ages from the appearance of the pods.

\begin{tabular}{|c|c|c|c|c|c|c|c|c|c|}
\hline \multirow{2}{*}{ Parameter } & \multirow{2}{*}{ Item } & \multicolumn{8}{|c|}{ Pods age, day from appearance of the flower } \\
\hline & & 10 & 13 & 16 & 19 & 22 & 25 & 28 & 31 \\
\hline \multirow{2}{*}{$\begin{array}{l}\text { Length, } \\
\mathrm{mm}\end{array}$} & Range & $44-60$ & $84.65-120$ & $110-114$ & $115-127$ & $130-145$ & $135-146$ & $135-163$ & $172-185$ \\
\hline & Arithmatic mean & 53.03 & 97.55 & 111.92 & 121.97 & 138.32 & 141.20 & 145.50 & 178.97 \\
\hline \multirow{2}{*}{$\begin{array}{l}\text { Max. } \\
\text { diameter, } \\
\text { mm }\end{array}$} & Range & $1.78-2.96$ & $3.80-6.08$ & $4.67-6.51$ & $5.86-7.77$ & $7.23-8.19$ & $7.61-9.04$ & $7.68-9.09$ & $8.88-9.62$ \\
\hline & Arithmatic mean & 2.43 & 4.86 & 5.73 & 6.76 & 7.73 & 8.43 & 8.58 & 9.34 \\
\hline \multirow{2}{*}{$\begin{array}{l}\text { Min. } \\
\text { diameter, } \\
\mathrm{mm}\end{array}$} & Range & $1.46-2.74$ & $3.43-5.78$ & $4.39-6.16$ & $5.20-7.24$ & $6.64-8.05$ & $6.66-8.35$ & $6.84-8.77$ & $8.74-9.76$ \\
\hline & Arithmatic mean & 2.26 & 4.44 & 5.52 & 6.36 & 7.46 & 7.88 & 8.09 & 9.16 \\
\hline \multirow{2}{*}{ Mass, $\mathrm{g}$} & Range & $0.40-1.10$ & $0.93-2.20$ & $1.90-2.60$ & $2.20-3.80$ & $3.60-5.00$ & $4.40-5.40$ & $5.40-6.95$ & $7.45-9.40$ \\
\hline & Arithmatic mean & 0.78 & 1.58 & 2.29 & 2.99 & 4.39 & 4.90 & 6.04 & 8.19 \\
\hline \multicolumn{2}{|c|}{ Mean moisture content, $\%$} & 93.64 & 91.32 & 91.25 & 91.02 & 90.94 & 89.68 & 86.91 & 68.92 \\
\hline
\end{tabular}


Table (2 ): Statistical indices for the main dimensions of green bean pods.

\begin{tabular}{|c|c|c|c|c|c|c|c|c|c|}
\hline \multirow{2}{*}{$\begin{array}{l}\text { Statistical } \\
\text { Analysis }\end{array}$} & \multirow{2}{*}{ Properties } & \multicolumn{8}{|c|}{ Age from appearance of the flower, day } \\
\hline & & 10 & 13 & 16 & 19 & 22 & 25 & 28 & 31 \\
\hline \multirow{5}{*}{$\begin{array}{l}\text { Standard } \\
\text { deviation } \\
\text { (S.D.) }\end{array}$} & Length & 4.198 & 7.760 & 0.909 & 2.771 & 3.337 & 2.454 & 5.969 & 2.771 \\
\hline & Max. Diam. & 0.264 & 0.589 & 0.406 & 0.470 & 0.263 & 0.304 & 0.299 & 0.168 \\
\hline & Min. Diam. & 0.284 & 0.548 & 0.393 & 0.472 & 0.327 & 0.366 & 0.412 & 0.022 \\
\hline & Mass & 0.153 & 0.307 & 0.148 & 0.387 & 0.334 & 0.219 & 0.363 & 0.438 \\
\hline & Mois. Cont. & 0.418 & 1.070 & 1.909 & 0.736 & 0.353 & 0.404 & 0.931 & 1.674 \\
\hline \multirow{5}{*}{$\begin{array}{l}\text { Variance } \\
\left(\mathrm{S}^{2}\right)\end{array}$} & Length & 17.623 & 60.211 & 0.829 & 7.681 & 11.137 & 6.023 & 35.633 & 7.681 \\
\hline & Max. Diam. & 0.070 & 0.347 & 0.165 & 0.221 & 0.069 & 0.092 & 0.090 & 0.028 \\
\hline & Min. Diam. & 0.081 & 0.300 & 0.155 & 0.223 & 0.107 & 0.134 & 0.170 & 0.047 \\
\hline & Mass & 0.023 & 0.094 & 0.022 & 0.150 & 0.111 & 0.048 & 0.132 & 0.192 \\
\hline & Mois. Cont. & 0.175 & 1.146 & 0.208 & 0.542 & 0.125 & 0.163 & 0.866 & 2.803 \\
\hline \multirow{5}{*}{$\begin{array}{l}\text { Standard } \\
\text { Error } \\
\text { (Mean } \pm \\
\text { S.E) }\end{array}$} & Length & $53.03 \pm 0.42$ & $97.55 \pm 0.08$ & $111.92 \pm 0.09$ & $121.97 \pm 0.28$ & $138.32 \pm 0.34$ & $141.19 \pm 0.25$ & $145.49 \pm 0.59$ & $178.19 \pm 0.28$ \\
\hline & Max. Diam. & $2.43 \pm 0.03$ & $4.86 \pm 0.06$ & $5.73 \pm 0.04$ & $6.77 \pm 0.05$ & $7.73 \pm 0.03$ & $8.44 \pm 0.03$ & $8.58 \pm 0.03$ & $9.33 \pm 0.02$ \\
\hline & Min. Diam. & $2.26 \pm 0.03$ & $4.44 \pm 0.01$ & $5.52 \pm 0.04$ & $6.36 \pm 0.05$ & $7.46 \pm 0.03$ & $7.88 \pm 0.04$ & $8.09 \pm 0.04$ & $9.13 \pm 0.02$ \\
\hline & Mass & $0.78 \pm 0.02$ & $1.58 \pm 0.03$ & $2.29 \pm 0.02$ & $2.99 \pm 0.04$ & $4.39 \pm 0.03$ & $4.90 \pm 0.02$ & $6.05 \pm 0.04$ & $8.19 \pm 0.04$ \\
\hline & Mois. Cont. & $93.64 \pm 0.04$ & $91.32 \pm 0.11$ & $91.25 \pm 0.05$ & $91.02 \pm 0.07$ & $90.94 \pm 0.04$ & $89.68 \pm 0.04$ & $86.91 \pm 0.09$ & $68.92 \pm 0.17$ \\
\hline \multirow{5}{*}{$\begin{array}{l}\text { Coefficient } \\
\text { of variance } \\
\text { (C.V.), \% }\end{array}$} & Length & 0.079 & 0.080 & 0.008 & 0.023 & 0.024 & 0.017 & 0.041 & 0.015 \\
\hline & Max. Diam. & 0.109 & 0.121 & 0.071 & 0.069 & 0.034 & 0.036 & 0.035 & 0.018 \\
\hline & Min. Diam. & 0.126 & 0.123 & 0.071 & 0.074 & 0.044 & 0.046 & 0.051 & 0.024 \\
\hline & Mass & 0.196 & 0.194 & 0.065 & 0.130 & 0.076 & 0.045 & 0.060 & 0.530 \\
\hline & Mois. Cont. & 0.004 & 0.012 & 0.021 & 0.008 & 0.004 & 0.005 & 0.011 & 0.024 \\
\hline
\end{tabular}




\section{Sweet Pea's Pods:}

Table (3) indicates typical mean values along the arithmetic means of sweet peas pods samples at different ages from the appearance of the pods. Data show that the length increased from 45.7 to $75.99 \mathrm{~mm}$, maximum diameter increased from 10.78 to $15.26 \mathrm{~mm}$, and minimum diameter increased from 4.01 to $13.98 \mathrm{~mm}$. Although mass increased from 0.80 to $5.72 \mathrm{~g}$, the moisture content decreased from 90.91 to $84.53 \%$ for pods at 6 and 33 days, respectively.

It is noticed that the difference between maximum and minimum diameter is small and they increase slowly when the age of green bean pods increase, while the length increases fast at early ages until 21 days, after that the increasing becomes small while the pod's age while the length increases fast at early ages until 21 days, after that the increasing becomes small while the pod's age increases.

Using the mean values shown in Table (3), the following general equations were deduced to express the relationships between length $(L)$, maximum diameter $\left(D_{1}\right)$, minimum diameter $\left(D_{2}\right)$ and mass $(M)$ of sweet pea pods at different ages from the appearance of the pods from its flower.

For the first age (pods at 6 days):

$\mathrm{L}=4.24 \mathrm{D}_{1}=11.41 \mathrm{D}_{2}=57.13 \mathrm{M}$

For pods at 12 days:

$\mathrm{L}=4.50 \mathrm{D}_{1}=6.65 \mathrm{D}_{2}=24.38 \mathrm{M}$

For pods at 18 days:

$\mathrm{L}=4.91 \mathrm{D}_{1}=6.00 \mathrm{D}_{2}=18.07 \mathrm{M}$

For the last age (pods at 33 days):

$\mathrm{L}=4.98 \mathrm{D}_{1}=5.44 \mathrm{D}_{2}=13.28 \mathrm{M}$

Generally, the following equations summarize the relationships between

$\mathrm{L}, \mathrm{D}_{1}, \mathrm{D}_{2}$ and $\mathrm{M}$ as a function of the pod's age (A).

$\mathrm{L}=48.392+0.959 \mathrm{~A}, \mathrm{R}^{2}=0.781, \mathrm{~F}_{\text {Regression }}=3551$

$\mathrm{D}_{1}=11.340+0.139 \mathrm{~A}, \mathrm{R}^{2}=0.684, \mathrm{~F}_{\text {Regression }}=2159$

$\mathrm{D}_{2}=4.266+0.332 \mathrm{~A}, \mathrm{R}^{2}=0.844, \mathrm{~F}_{\text {Regression }}=5413$

$\mathrm{M}=0.452+0.165 \mathrm{~A}, \mathrm{R}^{2}=0.919, \mathrm{~F}_{\text {Regression }}=11272$

The equations (from 14 through 17) indicate that the age of the pods affects the pod's length $(\mathrm{L})$, pod's maximum diameter $\left(\mathrm{D}_{1}\right)$, pod's 
minimum diameter $\left(\mathrm{D}_{2}\right)$ and pod's mass $(\mathrm{M})$. The age effect on the maximum diameter $(68 \%)$ is less than the effect of the age on the other factors.

\subsection{Statistical analysis of samples:}

Typical mean values were obtained from 100 samples at each age from the appearance of pods. The statically indices of the main dimensions, mass and moisture content such as variance $\left(S^{2}\right)$, standard deviation $\left(\sigma_{n-}\right.$ 1), standard error (S. E.), and coefficient of variance (C.V., \%) were calculated and tabulated in Table (4) to show the dispersion of the measured values around the mean value of sweet pea pods. The maximum and the minimum values of coefficient of variance (C.V.) were 0.018 and $0.041 \%$ for length at pod's ages 15 and 12 days, respectively.

For maximum diameter, the maximum and minimum values were 0.070 and $0.027 \%$ for pods ages 9 and 30 days, respectively. But, for minimum diameter, the maximum and minimum values were 0.137 and $0.013 \%$ at pod's age 9 and 27 days, respectively.

For mass, the maximum and minimum values were 0.102 and $0.002 \%$ at pod's ages 12 and 6 days, respectively.

Finally, the maximum and the minimum values for moisture content were 0.002 and $0.020 \%$ for pods ages 6 and 30 days, respectively.

Finally, the maximum and the minimum values for moisture content were 0.002 and $0.020 \%$ for pods ages 6 and 30 days, respectively.

The users preferred green peas with some physical properties such as:

- Length is ranged from 61 to $73 \mathrm{~mm}$.

- Maximum diameter is ranged from 13 to $15 \mathrm{~mm}$.

- Minimum diameter is ranged from 9 to $13 \mathrm{~mm}$.

- Mass is ranged from 2.5 to $4.5 \mathrm{~g}$.

- The moisture content is ranged from 88.5 to $87 \%$. 
Table (3 ): Typical mean of samples of 100 sweet peas pods at different ages from the appearance of the pods.

\begin{tabular}{|c|c|c|c|c|c|c|c|c|c|c|c|}
\hline \multirow{2}{*}{ Parameter } & \multirow{2}{*}{ Item } & \multicolumn{10}{|c|}{ Pods age, day from appearance of the flower } \\
\hline & & 6 & 9 & 12 & 15 & 18 & 21 & 24 & 27 & 30 & 33 \\
\hline \multirow{2}{*}{$\begin{array}{l}\text { Length, } \\
\mathrm{mm}\end{array}$} & Range & $43-48$ & $54-64$ & $57-66$ & $\begin{array}{c}63- \\
68 \\
\end{array}$ & $63-74$ & $67-78$ & $67-78$ & $68-78$ & $69-7.9$ & $7.1-8.2$ \\
\hline & $\begin{array}{l}\text { Arithmetic } \\
\text { mean }\end{array}$ & 45.7 & 58.4 & 61.19 & 65.86 & 69.39 & 72.6 & 73.68 & 73.8 & 74.63 & 75.99 \\
\hline \multirow{2}{*}{$\begin{array}{l}\text { Max. } \\
\text { diameter, } \\
\text { mm }\end{array}$} & Range & $9.5-12.5$ & $\begin{array}{l}10.5- \\
14.30 \\
\end{array}$ & $\begin{array}{c}12.0- \\
15.4 \\
\end{array}$ & $\begin{array}{c}13.0- \\
15.1 \\
\end{array}$ & $\begin{array}{c}13.2- \\
15.2 \\
\end{array}$ & $14-16$ & $\begin{array}{c}14.1- \\
16 \\
\end{array}$ & $\begin{array}{c}14.2- \\
16.1 \\
\end{array}$ & $\begin{array}{c}14.3- \\
16.1 \\
\end{array}$ & $\begin{array}{c}14.3- \\
16.2 \\
\end{array}$ \\
\hline & $\begin{array}{l}\text { Arithmetic } \\
\text { mean }\end{array}$ & 10.78 & 12.73 & 13.6 & 13.94 & 14.14 & 14.81 & 14.91 & 15.09 & 15.19 & 15.26 \\
\hline \multirow{2}{*}{$\begin{array}{l}\text { Min. } \\
\text { diameter, } \\
\mathrm{mm}\end{array}$} & Range & $3.42-5$ & $5-9$ & $\begin{array}{c}7- \\
10.67 \\
\end{array}$ & $\begin{array}{c}9- \\
12.4 \\
\end{array}$ & $\begin{array}{c}10.2- \\
12.7 \\
\end{array}$ & $\begin{array}{l}11- \\
12.8 \\
\end{array}$ & $\begin{array}{l}11.3- \\
13.10 \\
\end{array}$ & $13-13.80$ & $\begin{array}{c}13.2- \\
14.1 \\
\end{array}$ & $\begin{array}{c}13.4- \\
14.5 \\
\end{array}$ \\
\hline & $\begin{array}{l}\text { Arithmetic } \\
\text { mean }\end{array}$ & 4.01 & 6.86 & 9.2 & 10.55 & 11.56 & 11.9 & 12.28 & 13.43 & 13.66 & 13.98 \\
\hline \multirow{2}{*}{ Mass, g } & Range & $0.65-1$ & $1.6-2.2$ & $2-3$ & $\begin{array}{c}2.9- \\
3.7 \\
\end{array}$ & $3.3-4.3$ & $3.6-5$ & $3.7-5.2$ & $4-5.3$ & $4.3-5.7$ & $5-6.4$ \\
\hline & $\begin{array}{l}\text { Arithmetic } \\
\text { mean }\end{array}$ & 0.8 & 1.89 & 2.51 & 3.29 & 3.84 & 4.34 & 4.47 & 4.73 & 5.04 & 5.72 \\
\hline \multicolumn{2}{|c|}{$\begin{array}{l}\text { Mean moisture content, } \\
\%\end{array}$} & 90.91 & 90.03 & 88.56 & 88.39 & 88.07 & 87.86 & 87.17 & 87.14 & 84.58 & 84.5 \\
\hline
\end{tabular}


Table (4): Statistical indices for the main dimensions of sweet peas pods.

\begin{tabular}{|c|c|c|c|c|c|c|c|c|c|c|c|}
\hline \multirow{2}{*}{$\begin{array}{l}\text { Statistical } \\
\text { Analysis }\end{array}$} & \multirow{2}{*}{ Properties } & \multicolumn{10}{|c|}{ Age from appearance of the flower, day } \\
\hline & & 6 & 9 & 12 & 15 & 18 & 21 & 24 & 27 & 30 & 33 \\
\hline \multirow{5}{*}{$\begin{array}{l}\text { Standard } \\
\text { deviation } \\
\left(\sigma_{\mathrm{n}-1}\right)\end{array}$} & Length & 1.118 & 2.293 & 2.522 & 1.156 & 2.555 & 2.487 & 2.517 & 2.387 & 2.322 & 2.515 \\
\hline & Max. Diam. & 0.725 & 0.895 & 0.644 & 0.461 & 0.464 & 0.432 & 0.410 & 0.418 & 0.412 & 0.445 \\
\hline & Min. Diam. & 0.360 & 0.941 & 0.753 & 0.867 & 0.629 & 0.459 & 0.449 & 0.176 & 0.220 & 0.280 \\
\hline & Mass & 0.081 & 0.130 & 0.255 & 0.199 & 0.227 & 0.331 & 0.360 & 0.311 & 0.293 & 0.301 \\
\hline & Mois. Cont. & 0.224 & 0.911 & 0.852 & 0.686 & 0.311 & 0.457 & 1.953 & 0.413 & 1.666 & 0.224 \\
\hline \multirow{5}{*}{$\begin{array}{l}\text { Variance } \\
\left(\mathrm{S}^{2}\right)\end{array}$} & Length & 1.249 & 5.259 & 6.361 & 1.336 & 6.530 & 6.187 & 6.336 & 5.697 & 5.393 & 6.327 \\
\hline & Max. Diam. & 0.525 & 0.802 & 0.414 & 0.212 & 0.215 & 0.187 & 0.168 & 0.175 & 0.170 & 0.198 \\
\hline & Min. Diam. & 0.130 & 0.885 & 0.567 & 0.752 & 0.395 & 0.211 & 0.202 & 0.031 & 0.048 & 0.079 \\
\hline & Mass & 0.007 & 0.017 & 0.065 & 0.040 & 0.052 & 0.109 & 0.130 & 0.097 & 0.086 & 0.091 \\
\hline & Mois. Cont. & 0.050 & 0.830 & 0.725 & 0.470 & 0.097 & 0.209 & 0.909 & 0.170 & 2.775 & 0.050 \\
\hline \multirow{5}{*}{$\begin{array}{l}\text { Standard } \\
\text { Error } \\
\text { (Mean } \pm \\
\text { S.E) }\end{array}$} & Length & $45.71 \pm 0.11$ & $58.41 \pm 0.23$ & $61.19 \pm 0.25$ & $65.86 \pm 0.12$ & $69.39 \pm 0.26$ & $72.59 \pm 0.25$ & $73.38 \pm 0.25$ & $73.79 \pm 0.24$ & $74.61 \pm 0.23$ & $75.99 \pm 0.25$ \\
\hline & Max. Diam. & $10.78 \pm 0.07$ & $12.73 \pm 0.09$ & $13.59 \pm 0.06$ & $13.44 \pm 0.05$ & $14.15 \pm 0.05$ & $14.81 \pm 0.04$ & $14.91 \pm 0.04$ & $15.09 \pm 0.04$ & $15.19 \pm 0.04$ & $15.26 \pm 0.05$ \\
\hline & Min. Diam. & $4.01 \pm 0.04$ & $6.86 \pm 0.09$ & $9.14 \pm 0.08$ & $10.56 \pm 0.09$ & $11.56 \pm 0.06$ & $11.90 \pm 0.05$ & $12.28 \pm 0.05$ & $13.43 \pm 0.02$ & $13.67 \pm 0.02$ & $13.98 \pm 0.03$ \\
\hline & Mass & $0.80 \pm 0.01$ & $1.87 \pm 0.01$ & $2.49 \pm 0.03$ & $3.29 \pm 0.02$ & $3.84 \pm 0.02$ & $4.34 \pm 0.03$ & $4.47 \pm 0.04$ & $4.74 \pm 0.03$ & $5.04 \pm 0.03$ & $5.72 \pm 0.03$ \\
\hline & Mois. Cont. & $90.91 \pm 0.02$ & $90.03 \pm 0.09$ & $88.48 \pm 0.09$ & $88.38 \pm 0.07$ & $88.07 \pm 0.03$ & $87.87 \pm 0.05$ & $87.17 \pm 0.09$ & $87.14 \pm 0.04$ & $84.58 \pm 0.17$ & $84.53 \pm 0.02$ \\
\hline \multirow{5}{*}{$\begin{array}{l}\text { Coefficient } \\
\text { of variance } \\
\text { (C.V.), \% }\end{array}$} & Length & \begin{tabular}{|l|}
0.024 \\
\end{tabular} & \begin{tabular}{|l|}
0.039 \\
\end{tabular} & \begin{tabular}{|l|}
0.041 \\
\end{tabular} & \begin{tabular}{|l|}
0.018 \\
\end{tabular} & 0.037 & 0.034 & 0.034 & 0.032 & 0.031 & 0.033 \\
\hline & Max. Diam. & 0.067 & 0.070 & 0.047 & 0.033 & 0.033 & 0.029 & 0.028 & 0.028 & 0.027 & 0.029 \\
\hline & Min. Diam. & 0.090 & 0.137 & 0.082 & 0.082 & 0.054 & 0.039 & 0.037 & 0.013 & 0.016 & 0.020 \\
\hline & Mass & 0.101 & 0.069 & 0.102 & 0.061 & 0.059 & 0.076 & 0.081 & 0.066 & 0.058 & 0.053 \\
\hline & Mois. Cont. & 0.002 & 0.010 & 0.010 & 0.008 & 0.004 & 0.005 & 0.011 & 0.005 & 0.020 & 0.003 \\
\hline
\end{tabular}




\section{Determining the optimal harvest time:}

The optimal harvest time snap bean pods for exporting, previous experience of experts of horticulture cleared that information such as size, mass were used to determine the harvest time of green bean pods were used: Length is ranged from 110 to $140 \mathrm{~mm}$, maximum diameter is ranged from 5.5 to $8.0 \mathrm{~mm}$, minimum diameter is ranged from 2.25 to $5 \mathrm{~mm}$, mass is ranged from 2.25 to $5 \mathrm{gm}$ and the moisture content is ranged from 89.8 to $91.17 \%$ at about 16 to 22 days from the appearance of the flower.

The optimal harvest time sweet pea's pods for exporting, previous experience of experts of horticulture cleared that information such as size, mass to determine the harvest time of green pea pods were used: Length is ranged from 61 to $73 \mathrm{~mm}$, maximum diameter is ranged from 13 to $15 \mathrm{~mm}$, minimum diameter is ranged from 9 to $13 \mathrm{~mm}$, mass is ranged from 2.5 to $4.5 \mathrm{gm}$ and the moisture content is ranged from 88.5 to $87 \%$ at about 12 to 18 days from the appearance of the flower.

\section{CONCOLUSION}

The obtained results can be summarized as the following:

1) The length of snap bean pods was ranged from 110 to $140 \mathrm{~mm}$, maximum diameter was ranged from 5.5 to $8.0 \mathrm{~mm}$, minimum diameter was ranged from 2.25 to $5.0 \mathrm{~mm}$, mass was ranged from 2.25 to $5.0 \mathrm{gm}$ and the moisture content was ranged from 89.8 to $91.17 \%$ at about 16 to 22 days from the appearance of the flower.

2) Both of pod's length (L), maximum diameter $\left(D_{1}\right)$, minimum diameter $\left(D_{2}\right)$ and mass were function of the snap bean pod's age $(A)$ as the following: $\mathrm{L}=23.866+4.863 \mathrm{~A}, \mathrm{D}_{1}=0.550+0.302 \mathrm{~A}, \mathrm{D}_{2}=0.328$ $+0.296 \mathrm{~A}$ and $\mathrm{M}=0.331 \mathrm{~A}-2.894$.

3) The length of sweet pea's pods was ranged from 61.0 to $73.0 \mathrm{~mm}$, maximum diameter was ranged from 13.0 to $15.0 \mathrm{~mm}$, minimum diameter was ranged from 9.0 to $13.0 \mathrm{~mm}$, mass was ranged from 2.5 to $4.5 \mathrm{gm}$ and the moisture content was ranged from 88.5 to $87.0 \%$ at about 12 to 18 days from the flower appearance. 
4) Both of pod's length (L), maximum diameter $\left(D_{1}\right)$, minimum diameter $\left(D_{2}\right)$ and mass were function of the sweet peas pod's age $(A)$ as the following: $\mathrm{L}=48.392+0.959 \mathrm{~A}, \mathrm{D}_{1}=11.340+0.139 \mathrm{~A}, \mathrm{D}_{2}=4.266$ $+0.332 \mathrm{~A}$, and $\mathrm{M}=0.452+0.165 \mathrm{~A}$.

\section{REFERENCES}

Acquaah, G. 2005. Horticulture. Principles and Practices. Person Prentice Hall. Third edition. 725-727.

Drost, D. 2005. Peas in the Garden. www. HG/Garden/2005-09.

El-Raie, A. E.; M. I. Ghonimy; W. M. Ibrahim and E. A. ElRahman. 2007. Determination of snap beans characteristics at the suitable time of harvesting. Misr J. of Agric. Eng. Vol. 24 No. (4): 923-939.

Gast, L. B. 1994. Harvest Maturity. Indicator for Fruits and Vegetables. Kansas State University. Agri. Experiment station and cooperative extension service. MF-1175. Pp. 1-4.

Hazelton, T. 2006. The specifications for export green peas. Specifications number 00111, issue No. oo3.

Malik, M. N. 2000. Horticulture. First edition. Biotech books. DELHI110035. Pp. 226.

Salunkhe, D. K. and Kadam, S. S. 1998. Handbook of vegetable. Production, composition, storage, and processing. Marcel Dekker, Inc. USA. Pp. 437-462.

Singh, N. P.; A. K. Bhardwaj; A. Kumar; K. M. Singh. 2004. Modern technology on vegetable production. International book distributing Co. (Publishing Div.).Pp. 189-199.

Wien, H. C. 1997. The Physiology of vegetable Crops. CAB International, USA. 


\section{الملخص العربي

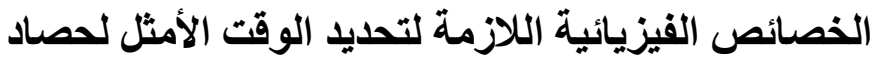 \\ محاصيل الفاصوليا والبسلة الخضراء التضائ}

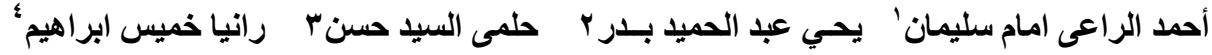

يعتمد الاقتصاد المصرى بشدة على القطاع الزراعى للغذاء و الكساء و غير ها من المنتجات.

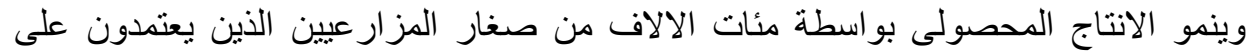

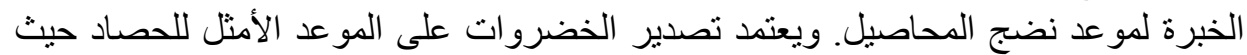

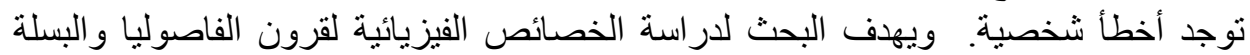

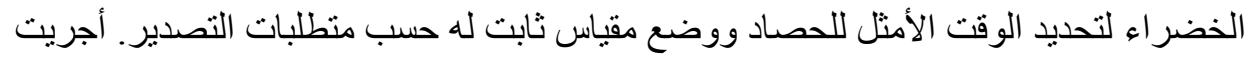

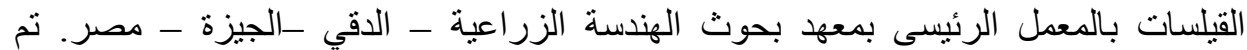

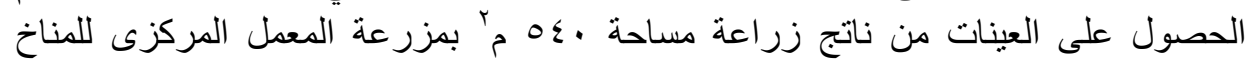

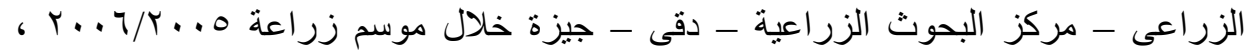

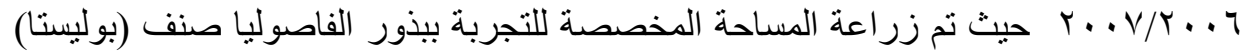

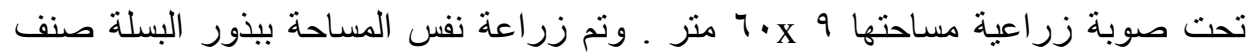

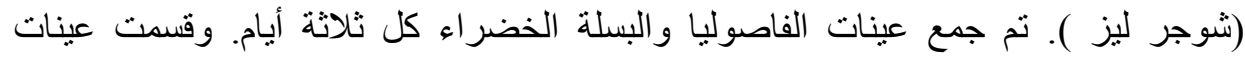

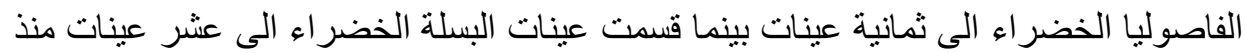
خروج القرن من الزهرة وحتى مرحلة الجفاف والاصفرار. ويمكن ايجاز النتائج التى تم

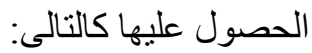

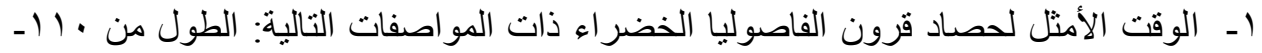

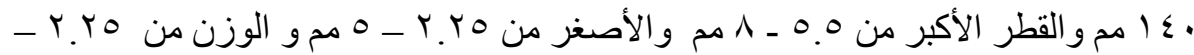

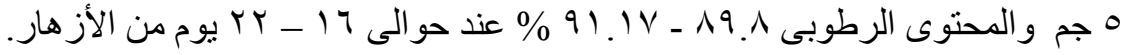

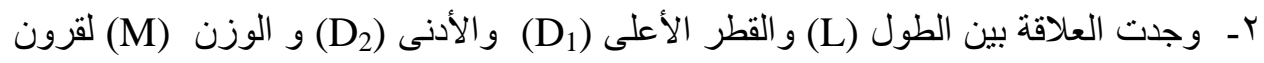

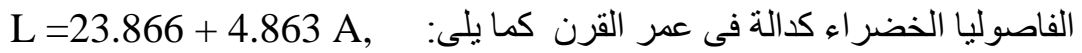
$\mathrm{D}_{1}=0.550+0.302 \mathrm{~A}, \mathrm{D}_{2}=0.328+0.296 \mathrm{~A}$ and $\mathrm{M}=0.331 \mathrm{~A}-2.894$

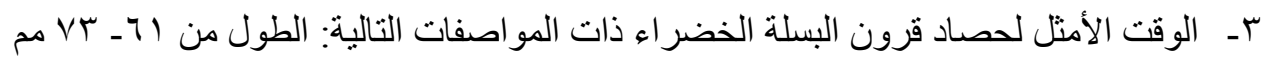

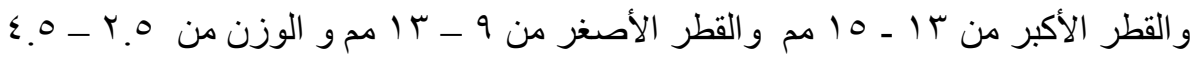

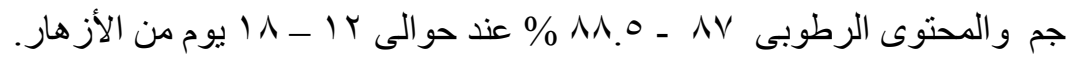

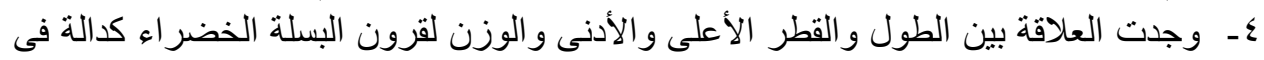

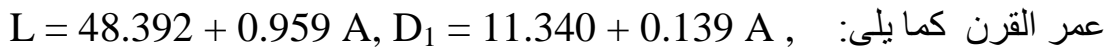
$\mathrm{D}_{2}=4.266+0.332$ and $\mathrm{M}=0.452+0.165 \mathrm{~A}$

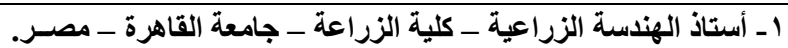

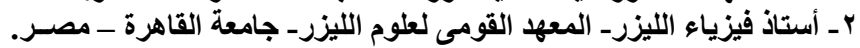

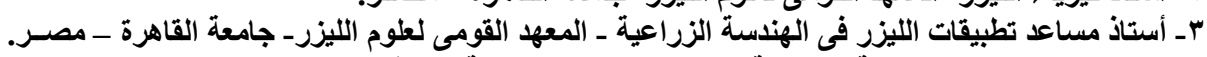

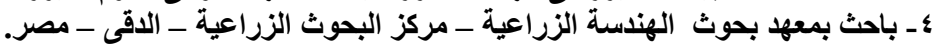

